\title{
QUEEN'S
UNIVERSITY
BELFAST
}

\section{Influence of nitrogen and sulfur fertilizers and inoculation with arbuscular mycorrhizal fungi on yield and pungency of spring onion}

Guo, T., Zhang, J. L., Christie, P., \& Li, X. L. (2006). Influence of nitrogen and sulfur fertilizers and inoculation with arbuscular mycorrhizal fungi on yield and pungency of spring onion. Journal of Plant Nutrition, 29(10), 17671778. https://doi.org/10.1080/01904160600897497

Published in:

Journal of Plant Nutrition

Queen's University Belfast - Research Portal:

Link to publication record in Queen's University Belfast Research Portal

\section{General rights}

Copyright for the publications made accessible via the Queen's University Belfast Research Portal is retained by the author(s) and / or other copyright owners and it is a condition of accessing these publications that users recognise and abide by the legal requirements associated with these rights.

Take down policy

The Research Portal is Queen's institutional repository that provides access to Queen's research output. Every effort has been made to ensure that content in the Research Portal does not infringe any person's rights, or applicable UK laws. If you discover content in the Research Portal that you believe breaches copyright or violates any law, please contact openaccess@qub.ac.uk. 


\title{
Influence of Nitrogen and Sulfur Fertilizers and Inoculation with Arbuscular Mycorrhizal Fungi on Yield and Pungency of Spring Onion
}

\author{
Tao Guo, ${ }^{1}$ Junling Zhang, ${ }^{1}$ Peter Christie, ${ }^{1,2}$ and Xiaolin Li ${ }^{1}$ \\ ${ }^{1}$ Key Laboratory of Plant Nutrition, Ministry of Agriculture; Key Laboratory of \\ Plant-Soil Interactions, Ministry of Education; and Department of Plant Nutrition, \\ College of Resources and Environmental Sciences, China Agricultural University, \\ Beijing, P.R. China \\ ${ }^{2}$ Agricultural and Environmental Science Department, Queen's University Belfast, \\ Belfast, UK
}

\begin{abstract}
A pot experiment was conducted out to investigate the yield and pungency of spring onion (Allium fistulosum L.) as affected by inoculation with arbuscular mycorrhizal (AM) fungi and addition of nitrogen $(\mathrm{N})$ and sulfur (S) fertilizers. Plants were inoculated with either Glomus mosseae or Glomus intraradices or grown as uninoculated controls. Two levels of $\mathrm{N}$ and $\mathrm{S}$ were applied to the soil in factorial combinations of 50 and $250 \mathrm{mg} \mathrm{N} \mathrm{kg}^{-1}$ soil and 0 and $60 \mathrm{mg} \mathrm{S} \mathrm{kg}^{-1}$ soil. Plants were grown in a greenhouse for 25 weeks and then harvested. Mycorrhizal colonization resulted in increased shoot dry weight, shoot-to-root ratio, shoot length, sheath diameter, and phosphorus $(\mathrm{P})$ concentrations. Shoot dry-matter yield was significantly affected by added N, but not by $S$. Shoot dry weight increased with increasing $\mathrm{N}$ supply (except for non-mycorrhizal controls without additional $\mathrm{S}$ fertilizer). Shoot total S concentration (TSC), enzyme-produced pyruvate (EPY), and organic sulfur concentration (OSC) in plants inoculated with Glomus mosseae were significantly lower than those of non-mycorrhizal controls, while these parameters in plants inoculated with Glomus intraradices were comparable to or higher than in the controls. Neither N nor S supply affected shoot EPY or OSC, whereas shoot TSC (except in plants inoculated with Glomus mosseae) and $\mathrm{SO}_{4}^{2-}$ concentrations were usually significantly increased by $\mathrm{S}$ supply. In soil of high $\mathrm{S}$ and low $\mathrm{P}$ availability, mycorrhizal colonization had a profound influence on both the yield and the pungency of spring onion.
\end{abstract}

Received 1 September 2005; accepted 5 January 2006.

Address correspondence to Dr. Junling Zhang, Department of Plant Nutrition, College of Resources and Environmental Sciences, China Agricultural University, Beijing 100094, P. R. China. E-mail: junlingz@cau.edu.cn or sgoffice@mx.cei.gov.cn 
Keywords: Glomus mosseae, Glomus intraradices, nitrogen; sulfur; Allium fistulosum, enzyme-produced pyruvate

\section{INTRODUCTION}

Spring onion and other Allium species produce aroma and flavor compounds that are recognized to have potential benefit for human health (Amagase et al., 2001). The flavor and aroma arise as the sulfur (S)-alk(en)yl-cysteine sulfoxides (ACSO) are enzymatically hydrolyzed to produce volatile $\mathrm{S}$ compounds and the by-products are pyruvic acid and ammonia. The composition and total concentrations of ACSO differ among the Allium species and cultivars (Yoo and Pike, 1998), and vary with the external environment (Randle and Lancaster, 2002). Detailed studies have been conducted on the composition of the flavor compounds in onion (Allium cepa L.). Results have shown that sulfur (S) supply is the primary environmental factor influencing the flavor compounds of onion plants. Higher available S generally results in greater flavor intensity (Randle, 1992; Randle et al., 1999) and changes in the composition of the ACSO and the biosynthetic intermediates (Randle et al., 1995; Coolong and Randle, 2003). Apart from $\mathrm{S}$ and nitrogen $(\mathrm{N})$ availability, the forms of $\mathrm{N}$ supplied have also been shown to affect growth, maturity, yield, flavor, and bulb quality (Gamiely et al., 1991; Randle, 2000; Coolong and Randle, 2003). In addition, $\mathrm{N}$ and S interact to affect flavor intensity (Coolong et al., 2004), the flavor biosynthetic pathway in onion (Coolong and Randle, 2003), and the alliin content of onion and garlic (Allium sativum) (Bloem et al., 2004).

Spring onion is a vegetable commonly used in China for flavoring in most Chinese dishes. In 2003 the total cultivated area of spring onion in China was 525,000 ha and total production was 17,630,000 tons, accounting for $2.92 \%$ of the total vegetable-cultivated area and $3.26 \%$ of vegetable production in the country. Shandong is the Chinese province with the largest cultivated area and production of spring onion, with values of 85,000 ha and 4.13 million, accounting for $16 \%$ of the total area and $23 \%$ of production nationwide in 2003 (Chinese Ministry of Agriculture, 2005). Considerable effort has been exerted over the years to increase the production of spring onion by the application of major fertilizer nutrients such as $\mathrm{N}$, phosphorus $(\mathrm{P})$, and potassium $(\mathrm{K})$. However, most of the effort has focused on increased yields, and factors influencing the flavor of spring onion have tended to be ignored, with little information on this topic found in the literature. It would, therefore, be of great interest to investigate the influence of $\mathrm{N}$ and $\mathrm{S}$ fertilizers on the growth and in particular the pungency of spring onion, to provide some insight into the regulation of flavor. Results of studies elsewhere have shown that growth and flavor can be increased by $\mathrm{N}$ and $\mathrm{S}$ fertilizers, but excessive supplies of $\mathrm{N}$ and $\mathrm{S}$ can lower yields and affect the quality of the plants (Randle, 2000; Randle and Lancaster, 2002). As spring onion is highly dependent on arbuscular mycorrhizal (AM) fungi, according 
to Tawaraya et al. (2001), and AM fungi have been shown to be effective in the enhancement of plant performance (in particular plant growth and nutrient uptake), the effects of AM fungi on the yield and pungency of spring onion were investigated in the present study.

\section{MATERIALS AND METHODS}

Soil was collected from the vicinity of Panggezhuang, Daxing district, Beijing. The soil was a sandy soil of low nutrient status with the following physicochemical properties (dry matter basis): $\mathrm{pH}$ (soil:water ratio of 1:2.5), 8.44; organic matter, 0.95\%; Kjeldahl N, 0.08\%; Olsen P $\left(0.5\right.$ mol L ${ }^{-1} \mathrm{NaHCO}_{3}$ extractable), $7.75 \mathrm{mg} \mathrm{kg}^{-1}$; and exchangeable $\mathrm{K}$ ( $\left.1 \mathrm{~mol} \mathrm{~L}^{-1} \mathrm{NH}_{4} \mathrm{OAc}\right), 33.6$ $\mathrm{mg} \mathrm{kg}^{-1}$. The soil was sieved $(<2 \mathrm{~mm})$ and sterilized by autoclaving at $120^{\circ} \mathrm{C}$ for $2 \mathrm{~h}$ and then air-dried.

The sterilized and air-dried soil was amended with $\mathrm{P}$ and $\mathrm{K}$ fertilizers in aqueous solution. Phosphorus was supplied at rates of 50 and $30 \mathrm{mg} \mathrm{kg}^{-1}$ as $\mathrm{Ca}\left(\mathrm{H}_{2} \mathrm{PO}_{4}\right)_{2}$ for non-mycorrhizal and mycorrhizal treatments, respectively. The different amounts of $\mathrm{P}$ supplied in mycorrhizal and non-mycorrhizal treatments were intended to reduce the difference in $\mathrm{P}$ nutrition between non-mycorrhizal and mycorrhizal plants. Potassium was supplied as $\mathrm{K}_{2} \mathrm{SO}_{4}$ (for the designated treatments) and $\mathrm{KCl}$ to obtain the rate of $150 \mathrm{mg} \mathrm{kg}^{-1}$ soil $\mathrm{K}$. There were two N-fertilizer rates, two S-fertilizer rates, and three mycorrhiza treatments in multifactorial combination to total 12 treatments. The soil was amended with two $\mathrm{N}$ rates ( 50 or $250 \mathrm{mg} \mathrm{N} \mathrm{kg}^{-1}$ as $\mathrm{NH}_{4} \mathrm{NO}_{3}$ solution) and two sulfur rates (0 and $60 \mathrm{mg} \mathrm{S} \mathrm{kg}^{-1}$ as $\mathrm{K}_{2} \mathrm{SO}_{4}$ solution). Pots were inoculated with $G$. mosseae (BEG 167) or G. intraradices (BEG 141) to produce arbuscular mycorrhiza and uninoculated pots served as non-mycorrhizal controls. The sulfur fertilizer was supplied as basal fertilizer. Fifty $\mathrm{mg} \mathrm{kg}^{-1} \mathrm{~N}$ was added as a basal fertilizer and the remaining $\mathrm{N}$ fertilizer was supplied at later stages of plant growth (weeks 15 and 20). There were four replicates of each treatment, for a total of 48 pots.

Soil $(1.8 \mathrm{~kg}$ ) was placed in each $2 \mathrm{~L}, 16 \mathrm{~cm}$ diameter plastic pot. Firstly, approximately $25 \%$ of the soil was placed in the base of the pot, followed by $60 \%$ of the soil mixed homogeneously with mycorrhizal inoculum. Finally, the remainder of the soil was placed on top. Mycorrhizal treatments received $180 \mathrm{~g}$ inoculum of Glomus mosseae (BEG167) or Glomus intraradices (BEG 141), while non-mycorrhizal plants received an equivalent amount of sterilized inoculum together with a filtrate $(0.45 \mu \mathrm{m}$ pore size $)$ of unsterilized soil to provide microflora similar except for the absence of the mycorrhizal fungus. The mycorrhizal inoculum consisted of loose soil containing spores and colonized maize-root fragments.

Seeds of spring onion were surface-sterilized in a $10 \%(\mathrm{v} / \mathrm{v})$ solution of hydrogen peroxide for $10 \mathrm{~min}$ and then washed thoroughly with deionized water. Approximately 60 seeds were sown in each pot. When the fourth leaves emerged, the seedlings were thinned to 30 per pot. 
The seedlings were irrigated with deionized water during the experiment. Soil moisture was regularly maintained at $60 \%-70 \%$ of field capacity by weighing. Plants were grown for 25 weeks from April 2004 to September 2004 in a greenhouse at the Department of Plant Nutrition, China Agricultural University. The plants were grown without supplementary illumination and with a daytime temperature range of $20^{\circ} \mathrm{C}-34^{\circ} \mathrm{C}$ and a night temperature range of $15^{\circ} \mathrm{C}-26^{\circ} \mathrm{C}$.

At harvest, the plants were separated into shoots and roots. Root samples $(0.5 \mathrm{~g}$ fresh weight) were cut into $1 \mathrm{~cm}$ long segments to determine the proportion of root length colonized by the mycorrhizal fungi as described by Giovannetti and Mosse (1980). Pungency as an indicator of onion flavor was measured by the pyruvic-acid method, namely the level of enzyme-produced pyruvate (EPY) (Randle, 1992; Randle et al., 1995). The higher the EPY, the more pungent the spring onion. The reaction of 2,4-dinitrophenylhydrazine (DNPH) with $\mathrm{NaOH}$ was used to detect the presence of pyruvic acid (enzymatically formed pyruvate). Shoot tissue ( $5 \mathrm{~g}$ fresh weight) was blended with equal volumes of water for 3-5 min. Equal aliquots of trichloroacetic acid and the slurry were combined after $20 \mathrm{~min}$, incubated for $1 \mathrm{~h}$, then filtered through cheesecloth. One millileter of the filtrate was added to $1 \mathrm{~mL}$ $0.0125 \%$ 2,4-dinitro-phenylhydrazine in $2 \mathrm{mg} \mathrm{L}^{-1} \mathrm{HCl}$ plus $1 \mathrm{~mL}$ water and incubated at $37^{\circ} \mathrm{C}$ for 10 minutes. Five millileters of $0.6 \mathrm{ml} \mathrm{L}^{-1} \mathrm{NaOH}$ was then added before the absorbance was read at $420 \mathrm{~nm}$ on a spectrophotometer. Pyruvate determinations were made against a sodium pyruvate standard curve.

The remainder of each plant sample was dried in an air-forced oven at $70^{\circ} \mathrm{C}$ for $48 \mathrm{~h}$ and weighed to determine dry-matter yield. Dry samples were milled with a high-speed multifunction micro-pulverizer (whirl type, ModelY60 , Hebei, China) prior to elemental analysis. For the measurement of $\mathrm{P}$ and $\mathrm{N}$ concentrations, subsamples (about $0.3 \mathrm{~g}$ ) were wet-digested on a block digester (Kjeldatherm, Gerhardt, Germany) with $\mathrm{H}_{2} \mathrm{SO}_{4}$ and $\mathrm{H}_{2} \mathrm{O}_{2}$. Plant $\mathrm{N}$ concentrations were determined using a micro-Kjeldahl method (Hendershot, 1985) and $\mathrm{P}$ concentrations by the vanado-molybdate method (Colwell, 1965) using a Shimadzu UV-120-02 spectrophotometer.

Total S concentrations were determined as described by Gaines and Mitchell (1979). Plant tissue was dried at $70^{\circ} \mathrm{C}$ for $72 \mathrm{~h}$ in a forced-air oven, then ground to pass through a $0.5 \mathrm{~mm}$ screen. Total $\mathrm{S}$ was oxidized to $\mathrm{SO}_{4}^{2-}$ by heating the dried tissue with $\mathrm{Mg}\left(\mathrm{NO}_{3}\right)_{2} \cdot 6 \mathrm{H}_{2} \mathrm{O}$. The samples were then ashed to the elemental state in a muffle furnace. Sulfate was extracted by dissolving the ash in hot, diluted $\mathrm{HCl}$. The dissolved $\mathrm{SO}_{4}^{2-}$ was precipitated with barium chloride and percentage total $\mathrm{S}$ was determined turbidimetrically with a spectrophotometer at $420 \mathrm{~nm}$ against a $\mathrm{CaSO}_{4} \cdot 2 \mathrm{H}_{2} \mathrm{O}$ standard curve. Plant tissue $\mathrm{SO}_{4}^{2-}$ was determined following the same method, but without the addition of the $\mathrm{Mg}\left(\mathrm{NO}_{3}\right)_{2} \cdot 6 \mathrm{H}_{2} \mathrm{O}$ prior to ashing. Organic $\mathrm{S}$ was calculated by subtracting sulfate $\mathrm{S}$ from total $\mathrm{S}$. 


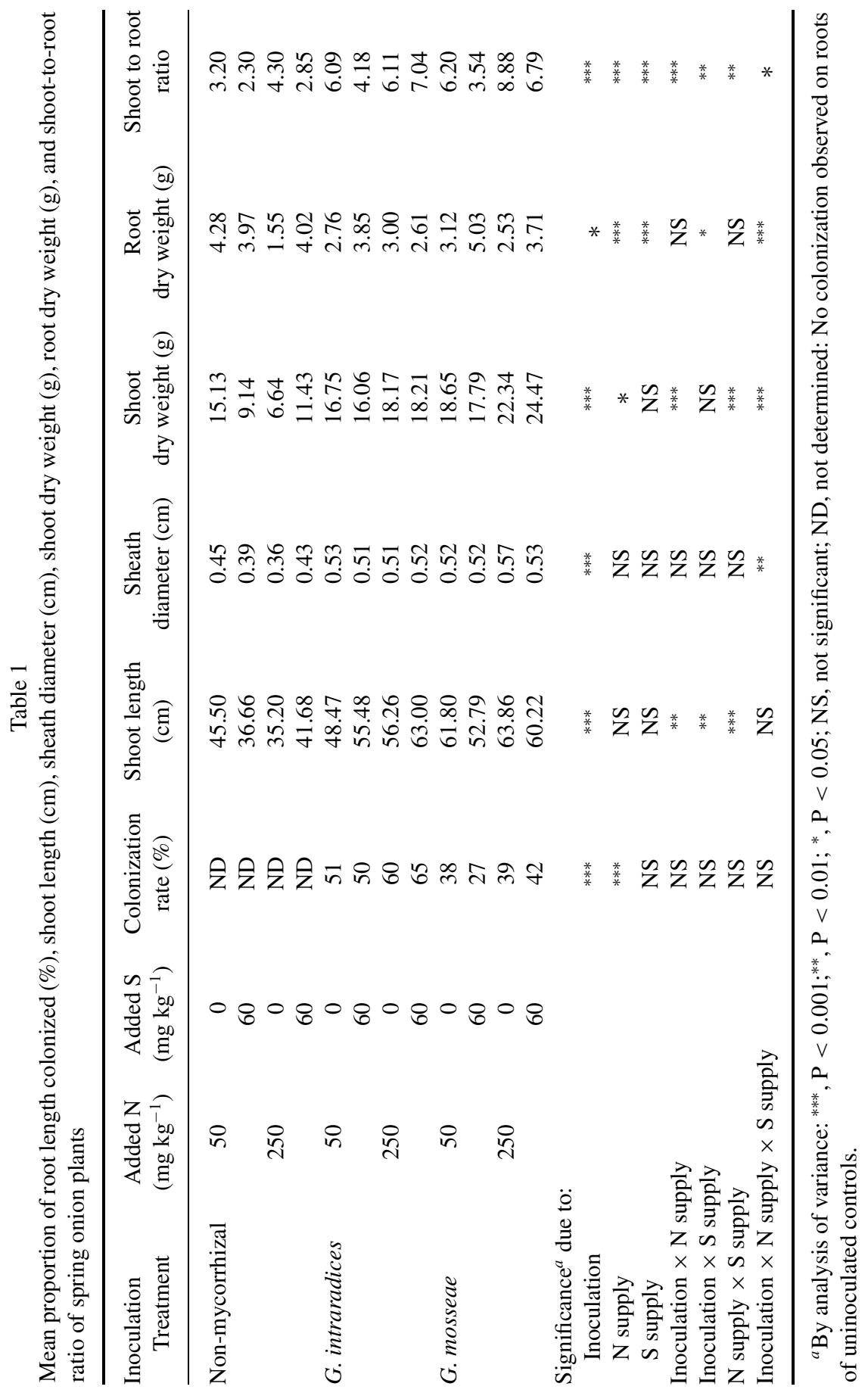


The data were analyzed by three-way analysis of variance using the SAS statistical software package (Version 6.12; SAS Institute, Cary, NC).

\section{RESULTS}

No AM colonization was observed on the roots of the control plants (Table 1). Roots of inoculated plants were extensively mycorrhizal, with the mean proportion of root length colonized ranging from $27 \%$ to $65 \%$. The colonization rate was significantly affected by $\mathrm{N}$ supply, but not by $\mathrm{S}$ supply. The colonization rate increased with increasing $\mathrm{N}$ supply. Plants inoculated with $G$. intraradices had a higher root colonization rate than those inoculated with $G$. mosseae $(\mathrm{P}<0.001)$.

Shoot length and sheath diameter were significantly increased by mycorrhizal colonization compared with the controls, but were not affected by $\mathrm{N}$ or S supply (Table 1). Shoot dry weight of mycorrhizal plants was significantly higher than that of non-mycorrhizal controls (Table 1). Plants inoculated with $G$. mosseae had higher shoot biomass than those inoculated with $G$. intraradices. Shoot dry weight was significantly increased by N (except in non-mycorrhizal plants given zero $\mathrm{S}$ ) but not by $\mathrm{S}$. Shoot dry-matter yields of mycorrhizal plants were highest at the highest supply levels of $\mathrm{N}$ and $\mathrm{S}$ examined, while yields of non-mycorrhizal controls showed the opposite trend $(\mathrm{P}<0.001)$.

Root dry weights of the spring onion were little affected by mycorrhizal colonization (Table 1). Root yields were significantly affected in a similar fashion by both $\mathrm{N}$ and $\mathrm{S}$ fertilizers. Mycorrhizal colonization and $\mathrm{N}$ fertilizer resulted in greater shoot-to-root ratio, and S supply resulted in lower shoot-to-root ratio (except at the higher fertilizer $\mathrm{N}$ rate for plants inoculated with $G$. intraradices).

As expected, $\mathrm{P}$ concentrations in the shoots and roots of mycorrhizal plants were significantly higher than in the non-mycorrhizal controls at all $\mathrm{N}$ and $\mathrm{S}$ levels examined (Table 2). The higher $\mathrm{N}$ rate resulted in significantly decreased shoot $\mathrm{P}$ concentrations (except in non-mycorrhizal plants with added $\mathrm{S}$ ), and $\mathrm{S}$ supply decreased root $\mathrm{P}$ concentrations (except in plants inoculated with $G$. intraradices receiving the lower $\mathrm{N}$-application rate).

Nitrogen concentrations in shoots and roots of mycorrhizal plants were significantly lower than in the non-mycorrhizal controls, except shoot $\mathrm{N}$ concentrations in plants inoculated with $G$. intraradices receiving the high levels of N and $\mathrm{S}$ and in plants inoculated with $G$. mosseae with the lower levels of $\mathrm{N}$ and $\mathrm{S}$, and root $\mathrm{N}$ concentration in plants inoculated with $G$. intraradices with the lower levels of $\mathrm{N}$ and $\mathrm{S}$. Shoot and root $\mathrm{N}$ concentrations increased significantly with increasing $\mathrm{N}$ supply (Table 2).

The EPY values in shoots of plants inoculated with $G$. intraradices were comparable to those in non-mycorrhizal controls. In contrast, EPY values in shoots of plants inoculated with G. mosseae were significantly lower (Table 3). Neither N nor S supply significantly affected shoot EPY. 
Table 2

Nitrogen $(\mathrm{N})$ and phosphorus $(\mathrm{N})$ concentrations in spring onion plants

\begin{tabular}{|c|c|c|c|c|c|c|}
\hline $\begin{array}{c}\text { Inoculation } \\
\text { treatment }\end{array}$ & $\begin{array}{c}\text { Added N } \\
\left(\mathrm{mg} \mathrm{kg}^{-1}\right)\end{array}$ & $\begin{array}{c}\text { Added S } \\
\left(\mathrm{mg} \mathrm{kg}^{-1}\right)\end{array}$ & $\begin{array}{c}\text { Shoot N } \\
(\%)\end{array}$ & $\begin{array}{c}\text { Shoot P } \\
(\%)\end{array}$ & $\begin{array}{c}\text { Root N } \\
(\%)\end{array}$ & $\begin{array}{c}\text { Root P } \\
(\%)\end{array}$ \\
\hline \multirow{4}{*}{ Non-mycorrhizal } & \multirow[t]{2}{*}{50} & 0 & 1.56 & 0.15 & 1.69 & 0.16 \\
\hline & & 60 & 2.02 & 0.12 & 2.09 & 0.13 \\
\hline & \multirow[t]{2}{*}{250} & 0 & 2.38 & 0.12 & 2.64 & 0.15 \\
\hline & & 60 & 2.08 & 0.12 & 2.30 & 0.13 \\
\hline \multirow[t]{4}{*}{ G. intraradices } & \multirow[t]{2}{*}{50} & 0 & 1.51 & 0.21 & 1.82 & 0.19 \\
\hline & & 60 & 1.24 & 0.23 & 1.47 & 0.19 \\
\hline & \multirow[t]{2}{*}{250} & 0 & 1.94 & 0.20 & 2.24 & 0.21 \\
\hline & & 60 & 2.26 & 0.21 & 2.12 & 0.18 \\
\hline \multirow[t]{4}{*}{ G. mosseae } & \multirow[t]{2}{*}{50} & 0 & 1.58 & 0.26 & 1.68 & 0.23 \\
\hline & & 60 & 1.29 & 0.22 & 1.34 & 0.22 \\
\hline & \multirow[t]{2}{*}{250} & 0 & 2.26 & 0.20 & 2.12 & 0.25 \\
\hline & & 60 & 1.98 & 0.19 & 1.90 & 0.22 \\
\hline \multicolumn{7}{|c|}{ Significance $^{a}$ due to: } \\
\hline \multicolumn{3}{|c|}{ Inoculation } & $* *$ & $* * *$ & $* * *$ & $* * *$ \\
\hline \multicolumn{3}{|l|}{$\mathrm{N}$ supply } & $* * *$ & $* *$ & $* * *$ & NS \\
\hline \multicolumn{3}{|l|}{ S supply } & NS & NS & NS & * \\
\hline \multicolumn{3}{|c|}{ Inoculation $\times \mathrm{N}$ supply } & NS & $* * *$ & NS & NS \\
\hline \multicolumn{3}{|c|}{ Inoculation $\times \mathrm{S}$ supply } & $*$ & $*$ & NS & NS \\
\hline \multicolumn{3}{|c|}{$\mathrm{N}$ supply $\times \mathrm{S}$ supply } & NS & NS & NS & NS \\
\hline \multicolumn{3}{|c|}{ Inoculation $\times \mathrm{N}$ supply $\times \mathrm{S}$ supply } & $* * *$ & NS & $*$ & NS \\
\hline
\end{tabular}

${ }^{a}$ By analysis of variance; ${ }^{* * *}: \mathrm{P}<0.001 ;{ }^{* *}, \mathrm{P}<0.01$; $^{*}, \mathrm{P}<0.05$; NS, not significant.

Compared with non-mycorrhizal plants, total sulfur concentrations (TSC) were usually higher in shoots of plants inoculated with $G$. intraradices and lower in shoots of plants inoculated with G. mosseae (Table 3). Sulfur application and higher N supply tended to increase shoot TSC in plants inoculated with $G$. intraradices, but decreased TSC in plants inoculated with G. mosseae. Sulfur application increased shoot TSC in plants inoculated with $G$. intraradices and in non-mycorrhizal controls.

Shoot $\mathrm{SO}_{4}^{2-}$ concentrations were influenced by $\mathrm{N}$ and $\mathrm{S}$ supply but not by mycorrhizal colonization (Table 3 ). Sulfur supply generally increased shoot $\mathrm{SO}_{4}^{2-}$ concentrations regardless of mycorrhizal treatment. Higher $\mathrm{N}$ supply increased shoot $\mathrm{SO}_{4}^{2-}$ concentrations in non-mycorrhizal controls and plants inoculated with $G$. intraradices. Compared with the controls, shoot organic sulfur concentrations (OSC) increased in plants inoculated with $G$. intraradices at the higher $\mathrm{N}$ application rate but decreased in plants inoculated with $G$. mosseae at all $\mathrm{N}$ and $\mathrm{S}$ combinations. Neither $\mathrm{N}$ nor $\mathrm{S}$ supply significantly affected shoot OSC. 
Table 3

Shoot enzyme-produced pyruvate (EPY), total sulfur concentration (TSC), $\mathrm{SO}_{4}^{2-}$ concentration, and organic sulfur concentration (OSC) of spring onion plants

\begin{tabular}{|c|c|c|c|c|c|c|}
\hline $\begin{array}{l}\text { Inoculation } \\
\text { treatment }\end{array}$ & $\begin{array}{c}\text { Added N } \\
\left(\mathrm{mg} \mathrm{kg}^{-1}\right)\end{array}$ & $\begin{array}{c}\text { Added S } \\
\left(\mathrm{mg} \mathrm{kg}^{-1}\right)\end{array}$ & $\begin{array}{c}\text { EPY } \\
\left(\mu \mathrm{mol} \mathrm{g}^{-1}\right)\end{array}$ & $\begin{array}{c}\mathrm{TSC}(\%) \\
(\%)\end{array}$ & $\mathrm{SO}_{4}^{2-}$ & $\begin{array}{l}\mathrm{OSC} \\
(\%)\end{array}$ \\
\hline \multirow[t]{4}{*}{ Non-mycorrhizal } & \multirow[t]{2}{*}{50} & 0 & 8.00 & 0.40 & 0.20 & 0.20 \\
\hline & & 60 & 12.80 & 0.55 & 0.29 & 0.27 \\
\hline & \multirow[t]{2}{*}{250} & 0 & 10.75 & 0.48 & 0.25 & 0.22 \\
\hline & & 60 & 10.92 & 0.51 & 0.31 & 0.20 \\
\hline \multirow[t]{4}{*}{ G. intraradices } & \multirow[t]{2}{*}{50} & 0 & 9.53 & 0.44 & 0.24 & 0.20 \\
\hline & & 60 & 9.34 & 0.45 & 0.24 & 0.20 \\
\hline & \multirow[t]{2}{*}{250} & 0 & 11.03 & 0.51 & 0.26 & 0.25 \\
\hline & & 60 & 10.50 & 0.58 & 0.27 & 0.31 \\
\hline \multirow[t]{4}{*}{ G. mosseae } & \multirow[t]{2}{*}{50} & 0 & 7.85 & 0.42 & 0.25 & 0.17 \\
\hline & & 60 & 10.15 & 0.41 & 0.26 & 0.15 \\
\hline & \multirow[t]{2}{*}{250} & 0 & 6.44 & 0.41 & 0.25 & 0.16 \\
\hline & & 60 & 5.61 & 0.38 & 0.26 & 0.12 \\
\hline \multicolumn{7}{|c|}{ Significance $^{\mathrm{a}}$ due to: } \\
\hline \multicolumn{3}{|l|}{ Inoculation } & $* * *$ & $* * *$ & NS & $* * *$ \\
\hline \multicolumn{3}{|l|}{ N supply } & NS & $*$ & $*$ & NS \\
\hline \multicolumn{3}{|l|}{ S supply } & NS & $*$ & $* *$ & NS \\
\hline \multicolumn{3}{|c|}{ Inoculation $\times \mathrm{N}$ supply } & $*$ & $*$ & NS & $*$ \\
\hline \multicolumn{3}{|c|}{ Inoculation $\times \mathrm{S}$ supply } & NS & $*$ & $*$ & NS \\
\hline \multicolumn{3}{|c|}{$\mathrm{N}$ supply $\times \mathrm{S}$ supply } & $*$ & NS & NS & NS \\
\hline \multicolumn{3}{|c|}{ Inoculation $\times \mathrm{N}$ supply $\times \mathrm{S}$ supply } & NS & NS & NS & NS \\
\hline
\end{tabular}

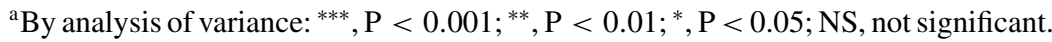

\section{DISCUSSION}

As expected, mycorrhizal inoculation resulted in enhanced shoot yields in spring onion plants at all combinations of $\mathrm{N}$ and $\mathrm{S}$ investigated (Table 1), and the growth-promoting effect was accompanied by increased $\mathrm{P}$ uptake and was greater than the increase in shoot growth due to the $\mathrm{N}$ fertilizer (Tables 1 and 2). Our results are consistent with the findings of Tawaraya et al. (1996, 1999, 2001) and Matsubara et al. (2002) who also found that spring onion had a high mycorrhizal dependency, and that plant growth and $\mathrm{P}$ uptake were higher in mycorrhizal plants than in the controls. The decrease in root growth (except at high $\mathrm{N}$ and low S supply) and increase in shoot-to-root ratio in mycorrhizal plants imply that mycorrhizal fungi contribute to the growth-promoting factors. The shoot dry-matter yield of plants inoculated with $G$. mosseae was often higher than that of those inoculated with $G$. intraradices at all $\mathrm{N}$ and $\mathrm{S}$ combinations examined, indicating that AM fungal species vary in their effects on growth of their host plants. 
Early results of Rhodes and Gerdemann (1978) showed that mycorrhizae can take up S. In the present experiment, shoot TSC and OSC, but not shoot $\mathrm{SO}_{4}^{2-}$ concentrations, were influenced by mycorrhizal colonization (Table 3 ). Plants inoculated with $G$. mosseae had significantly lower values for these parameters compared with the control plants, and these parameters in plants inoculated with $G$. intraradices were comparable with or higher than in the controls. Our results indicate that mycorrhizal fungi may mediate the uptake and assimilation of $\mathrm{S}$ and the partitioning of $\mathrm{S}$ in the plants, and subsequently affect EPY in spring onion. Compared with the controls and plants inoculated with $G$. intraradices, it is likely that plants inoculated with $G$. mosseae took up less S and partitioned less $S$ into organosulfur compounds and, as a consequence, EPY was reduced in these plants. Therefore, plants inoculated with $G$. mosseae had less pungency. One of our previous experiments also showed that onion plants inoculated with $G$. intraradices often had higher bulb EPY and shoot TSC and OSC compared with non-mycorrhizal controls, and those inoculated with $G$. versiforme tended to have lower EPY, TSC, and OSC. Our results suggest that mycorrhizal colonization may influence the flavor intensity of Allium plants, and the changes in flavor intensity may be related to the fungal species involved.

Numerous studies on onion plants have shown that $\mathrm{N}$ and $\mathrm{S}$ supply have considerable influence on the yield, flavor intensity, and composition of the plants. Nitrogen supply has often been shown to have profound effects on the development and yield aspects, while $S$ supply has been found to be the primary environmental factor influencing plant flavor intensity (Randle and Lancaster, 2002). Increased shoot yields at higher N supply (except shoot yield of nonmycorrhizal plants without additional S supply) were found in the present study. Higher N supply led to greater shoot growth, at the expense of root growth, as shown by the increase in shoot-to-root ratio regardless of the mycorrhizal treatment.

Neither N supply nor S supply significantly affected EPY or shoot OSC, although shoot TSC and shoot $\mathrm{SO}_{4}^{2-}$ were significantly affected. Our results differ from those of Randle (1992, 2000) and Randle et al. (1995), who showed that EPY was affected by $\mathrm{N}$ and $\mathrm{S}$ availability in the substrate. These workers have suggested that the poor correlations between total bulb $\mathrm{S}$ concentration and pungency among onion cultivars of broad genetic background may be explained by differential partitioning of $S$ into flavor and non-flavor compounds (Randle, 1992; Randle and Bussard, 1993). It is generally known that sulfate taken up by plant roots is transported to the leaves and is then either stored in the vacuole or reduced to sulfide and assimilated into cysteine in the chloroplasts for the subsequent synthesis of proteins or methionine and glutathione (Hell and Rennenberg, 1998). Cysteine and glutathione serve as precursors to several gamma-glutamyl peptides (rGP), which are used in the flavor biosynthetic pathway (Randle and Lancaster, 2002). In the present experiment, soil $\mathrm{S}$ availability was not a limiting factor for plant growth; therefore, $\mathrm{S}$ derived from the higher $\mathrm{S}$ supply may have been stored $\mathrm{as}^{2-}$ and isolated from the 
flavor precursor synthesis route, or was used for the synthesis of non-flavor compounds. Randle et al. (1995) showed that $95 \%$ of the organically bound S in onion bulbs grown with low $\mathrm{S}$ fertility could be attributed to the compounds in the flavor biosynthetic pathway, and with increased S supply only $40 \%$ of the total bulb S could be attributed to the ACSO and the biosynthetic intermediates. A similar experiment conducted by Bloem et al. (2004) also showed that alliin concentrations in the leaves and bulbs of onion and garlic were not affected by $\mathrm{N}$ supply in the substrate. As it is generally accepted that $\mathrm{S}$ fertility is a primary factor in greatly altering onion flavor, it was not unexpected that $\mathrm{N}$ availability had no significant effect on EPY.

Nitrogen and $\mathrm{S}$ availability have been shown to interact to affect the flavor precursors and their peptide intermediates in onion bulbs (Coolong and Randle, 2003), and the alliin content in the leaves and bulbs of onion and garlic (Bloem et al., 2004). In the present experiment, higher $\mathrm{N}$ supply and $\mathrm{S}$ fertilizer rate interacted to increase shoot dry-matter yield in mycorrhizal plants but decreased EPY in plants inoculated with G. mosseae. The results of Coolong and Randle (2003) indicated that the effects of $\mathrm{N}$ and $\mathrm{S}$ on the flavor pathway diminish as each becomes present in adequate or excessive levels. Our results and those of other investigators imply that in order to maximize the $\mathrm{N}$ and $\mathrm{S}$ interaction, a broad $\mathrm{N}$ and $\mathrm{S}$ fertilizer regime should be used and substrates with low $\mathrm{N}$ and $\mathrm{S}$ availability should be selected.

Our results show that mycorrhizal colonization can contribute substantially to the growth and pungency of spring onion, and that the effects of mycorrhizal colonization are related to the fungal isolates involved. Whereas $\mathrm{N}$ and $\mathrm{S}$ fertilizers do not affect the pungency of spring onion, our results indicate the possibility of inoculating plants grown in soil of high $\mathrm{S}$ and low $\mathrm{P}$ availability with suitable fungal species to increase the yield and to control flavor intensity for consumers. In addition, the promotion of arbuscular mycorrhizal colonization has the advantage of permitting reduced nutrient inputs into the environment. A wider range of AM fungal species need to be investigated in field experiments to elucidate fully their potential role in the management of spring onion yield and bulb quality.

\section{ACKNOWLEDGMENTS}

This work was funded by the National Natural Science Foundation of China [Projects 30200168 and GZ051-11(155)] and the Royal Society (China Exchanges Project 15360).

\section{REFERENCES}

Amagase, H., B. L. Petesch, H. Matsuura, S. Kasuga, and Y. Itakura. 2001. Intake of garlic and its bioactive components. Journal of Nutrition 131 (Supplement 3): 955S-962S. 
Bloem, E., S. Haneklaus, and E. Schnug. 2004. Influence of nitrogen and sulfur fertilization on the alliin content of onions and garlic. Journal of Plant Nutrition 27: 1827-1839.

Chinese Ministry of Agriculture. 2005. Table of spring onion and garlic production in the provinces of China in 2003. http://www.agri.gov. $\mathrm{cn} / \mathrm{sjzl} / 2003 / 161 . \mathrm{htm}$.

Colwell, J. D. 1965. An automatic procedure for the determination of phosphorus in sodium hydrogen carbonate extracts of soil. Chemistry and Industry (London) 21: 893-895.

Coolong, T. W., D. A. Kopsell, D. E. Kopsell, and W. M. Randle. 2004. Nitrogen and sulfur influence nutrient usage and accumulation in onion. Journal of Plant Nutrition 27: 1667-1686.

Coolong, T. W., and W. M. Randle. 2003. Sulfur and nitrogen availability interact to affect the flavor biosynthetic pathway in onion. Journal of the American Society for Horticultural Science 128: 776-783.

Gaines, T. P., and G. A. Mitchell. 1979. Chemical methods for soil and plant analysis, University of Georgia Coastal Plain Experimental Station Agronomy Handbook, 59-64. Tifton, GA: University of Georgia.

Gamiely, S., W. M. Randle, H. A. Mills, D. A. Smittle, and G. I. Banna. 1991. Onion plant growth, bulb quality, and water uptake following ammonium and nitrate nutrition. HortScience 26: 1061-1063.

Giovannetti, M., and B. Mosse. 1980. An evaluation of techniques for measuring vesicular arbuscular mycorrhizal infection in roots. New Phytologist 84: 489-500.

Hell, R., and H. Rennenberg. 1998. The plant sulphur cycle. In Sulphur in agroecosystems, ed. E. Schnug, 135-173. Dordrecht, Netherlands: Kluwer Academic Publishers.

Hendershot, W. H. 1985. An inexpensive block digester for nitrogen determination in soil samples. Communications in Soil Science and Plant Analysis 16: $1271-1278$.

Matsubara, Y. I., E. Suzumura, and H. Fukui. 2002. Application of arbuscular mycorrhizal fungi to plug seedling system in Welsh onion. Journal of the Japanese Society for Horticultural Science 71: 203-207.

Randle, W. M. 1992. Onion germplasm interacts with sulfur fertility for plant sulfur utilization and bulb pungency. Euphytica 59: 151-156.

Randle, W. M. 2000. Increasing nitrogen concentration in hydroponic solutions affects onion flavor and bulb quality. Journal of the American Society for Horticultural Science 125: 254-259.

Randle, W. M., and M. L. Bussard. 1993. Pungency and sugars of short-day onions as affected by sulfur nutrition. Journal of the American Society for Horticultural Science 118: 766-770.

Randle, W. M., D. E. Kopsell, D. A. Kopsell, and R. L. Snyder. 1999. Total sulfur and sulfate accumulation in onion is affected by sulfur fertility. Journal of Plant Nutrition 22: 45-51. 
Randle, W. M., and J. E. Lancaster. 2002. Sulphur compounds in alliums in relation to flavour quality. In Allium crop science: Recent advances, eds. H. Rabinowitch and L. Currah, 329-356. Wallingford, UK: CAB International.

Randle, W. M., J. E. Lancaster, M. L. Shaw, K. H. Sutton, R. L. Hay, and M. L. Bussard. 1995. Quantifying onion flavor compounds responding to sulfur fertility-Sulfur increases levels of alk(en)yl cysteine sulfoxides and biosynthetic intermediates. Journal of the American Society for Horticultural Science 120: 1075-1081.

Rhodes, L. H., and J. W. Gerdemann. 1978. Hyphal translocation and uptake of sulfur by vesicular-arbuscular mycorrhizae of onion. Soil Biology and Biochemistry 10: 355-360.

Tawaraya, K., T. Imai, and T. Wagatsuma. 1999. Importance of root length in mycorrhizal colonization of Welsh onion. Journal of Plant Nutrition 22: 589-596.

Tawaraya, K., T. Kinebuchi, S. Watanabe, T. Wagatsuma, and M. Suzuki. 1996. Effect of arbuscular mycorrhizal fungi Glomus mosseae, Glomus fasciculatum and Glomus caledonium on phosphorus uptake and growth of Welsh onion (Allium fistulosum L.) in Andosol. Japanese Journal of Soil Science and Plant Nutrition 67: 294-298.

Tawaraya, K., K. Tokairin, and T. Wagatsuma. 2001. Dependence of Allium fistulosum cultivars on the arbuscular mycorrhizal fungus, Glomus fasciculatum. Applied Soil Ecology 17: 119-124.

Yoo, K. S., and L. M. Pike. 1998. Determination of flavor precursor compound Salk(en)yl-L-cysteine sulfoxides by an HPLC method and their distribution in Allium species. Scientia Horticulturae 75: 1-10. 